\title{
Covid-19 Fatality Rate in Third World Countries: A Review of Environmental Challenges and Impacts on Public Health and Human Security
}

\author{
Chukwuemeka E. Etodike ${ }^{1, *}$, Elsie C. Ekeghalu², Kelechi Johnmary Ani ${ }^{3}$ and \\ Emmanuel Mutambara ${ }^{4}$
}

${ }^{1}$ Department of Psychology, Nnamdi Azikiwe University Awka, Nigeria

${ }^{2}$ Research and Statistics Unit, Alex Ekwueme Teaching Hospital, Abakaliki, Nigeria

${ }^{3}$ Department of History \& Strategic Studies, Alex Ekwueme Federal University Ndufu-Alike, Ikwo, Nigeria

${ }^{4}$ Graduate School of Business \& Leadership, Westville Campus, Durban. University of KwaZulu-Natal, South Africa

\begin{abstract}
The novel coronavirus is far from being over; with the case-fatality rate (CFR) hitting more than 16,500 globally as of July, there is a worry that despite the fact that the global CFR curve is showing signs of flattening, the environmental peculiarities of the third world countries may be abetting global efforts towards containing the virus. Therefore, this review x-rayed these peculiarities in the light of their current concern in public health as per their contribution to the persistent surge in CFR in most developing nations. Given that the virus is transmitted via droplets, the review focused on how the state of public and environmental challenges such as air as well as water pollution and personal hygiene could be abetting the surge in coronavirus infections and morbidity. The review revealed, among other things, that challenges associated with poor sanitary conditions, lack of potable water, unventilated environments, air pollution, and poor inter-personal hygiene are devastating challenges in the fight against the pandemic. The implication is that since these conditions are systematic in nature, it may take more than average effort and public sacrifice to checkmate the case-fatality rate of the virus in the third world. Therefore, call for studies is necessary to establish empiricism for CFR patterns and ratio across areas in deplorable environmental and sanitary conditions.
\end{abstract}

Keywords: Case fatality rate (CFR), covid-19 pandemic, communicable diseases, environment, lockdown, personal hygiene, public health.

\section{INTRODUCTION}

World Health Organization (WHO) announced a novel pandemic in February 2020. It is being caused by a virus that attacks the respiratory system known as acute respiratory syndrome coronavirus 2 (SARS-CoV2) and causes mild illnesses like: high fever, headache, cough, and pneumonia, etc. [1]. Omer et al. [2] contended that difficulty in breathing and death might occur in severe cases. At the moment, more than halfa-million lives have been lost globally in more than 16 million cases [3]. Despite moderate exposure to the pandemic, Nigeria's covid-19 figures stand at more than 800 deaths in more than 35,000 index cases [3].

The tension created by the pandemic is due to its rapid spread and high contagiousness through droplets, although it is not airborne [1, 4]. The global response to this panic and threat to human life saw drastic measures to safeguard lives; thus, self and public isolation, quarantine, and social distancing were initiated until a global lockdown became a necessary

*Address correspondence to this author at the Department of Psychology, Nnamdi Azikiwe University Awka, Nigeria; Tel: +2348066614744;

E-mail: nelsonetodike@gmail.com action [5]. The negative impacts are real, and adjusting to a new way of life is inevitable for survival.

Healthwise, the virus's persistence and lack of cure and vaccine created phobias, panics, anxiety, and depression, which became challenges to public health as the virus case fatality rate (CFR) ensued [6]. Although, Sen-Crowe et al. [4] contended that these measures have helped to checkmate the rate of its spread, however, the case fatality rate (CFR) may largely depend on changes in individual and public lifestyles, which are determined by personal and environmental practices such as personal hygiene and environmental hazards in the form of air and water pollution and poor sanitary environment. There is evidence in Ouyang et al.'s [7] study of OECD countries that environmental regulation is poor with high air pollution levels trailing economic growth. Regarding third-world countries such as Nigeria, the environmental peculiarities remain the greatest threat abetting the efforts towards containing the virus [8]. For instance, Zhao et al. [9] contended that the COVID-19 spread in African countries South Africa, Egypt, Algeria, Nigeria, Senegal, and Kenya could be predicted based on peculiarities of those countries 
which are common to the third world and among them are poor sanitary conditions.

Núñez-Delgado [10] emphasised that there are peculiarities to every epidemiology and that the evolution of COVID-19 virus in relation to other environmental factors such as water, air, wastewater, and sewage sludge is a critical determining factor in the race to checkmate the spread of the novel virus. Given this instance, the impacts of air and water pollution and personal hygiene on public health and safety in relation to the third world's unique developmental challenges in providing essentials to proper environmental health (portable water, good sanitary conditions, quality of air, good waste management, etc.) could be determining factors of CFR in the third world. Their importance is perhaps hinged on their predictive effects on epidemiology as co-morbid factors.

\section{REVIEW: ENVIRONMENTAL DETERMINANTS OF COVID-19 CASE FATALITY RATE IN THE THIRD WORLD}

\subsection{Air Pollution}

Coronavirus is not airborne [1] but is mainly transmitted through air droplets from person to person and can be contacted by coming in contact with objects upon which it has been dropped. Given its long half-life [8], chances of environmental contamination are high with air pollution [10], and therefore such environmental factors embody a high case-fatality rate. This implies that the more a person is exposed to pollute environments upon which the droplets have settled and contaminated, the greater chances of infection and fatality. Air pollution as an environmental factor typically challenges the containment of this novel virus as virus droplets can be hauled through the air through the pollution to people. This instance is very devastating, especially in the third world, where air pollution is among the greatest health hazards.

According to Fattorini and Regoli [11], air pollution could adversely affect coronavirus infection and spread. Apart from geographic factors that create differences in atmospheric pollution such as impacts in northern areas, chronicity of exposure, as depicted in the Italian CFR may well be abetting the infection rate. More threats exist in the long term air quality is polluted [11]. In Nigeria, like other third world countries, the level of contamination in the atmospheric air is alarming, with increasing evidence of respiratory and cardiac infections. These conditions are critical comorbidity factors to the virus [12]. Covid-19 has been linked to high correlation to affect people with heart disease more; cardiovascular disease as a comorbidity factor with coronavirus is associated with higher levels of death risks in patients due to induced myocardial injury, arrhythmia, acute coronary syndrome, and venous thromboembolism. These seem to be inevitable with the coronavirus infection [12]. Environmental pollution, especially air, is opposed to both heart disease and covid-19, further reducing the chances of surviving the infection. This is because atmospheric contamination may become a budding for pro-inflammatory responses [11]. Sadly, atmospheric pollution is high in our communities (third world countries) than elsewhere [13]. This ranges from pollutions from wastes, cars, industries, and machinery and pollution caused by human activities. The mechanism of the novel virus infection is suggestive that it is more likely to thrive in the polluted environment with an increased danger of fatality than in areas with effective management of air population.

\subsubsection{Critical Health Vulnerabilities of Air Pollution}

Air can be contaminated in diverse forms becoming chemical pollutants of either organic, e.g., benzo [a]pyrene or non-organic origins. These origins are usually vaporised as ozone $\left(\mathrm{O}_{3}\right)$, carbon monoxide (CO), nitrogen dioxide $\left(\mathrm{NO}_{2}\right)$, and sulphur dioxide $\left(\mathrm{SO}_{2}\right)$ or as polycyclic aromatic hydrocarbons (PAHs), monocyclic hydrocarbons benzene, toluene, xylene, and aliphatic chemicals, respectively for inorganic and organic origins [14, 15]. As much as there is fear about contaminated pollen in vaporised forms, whether they are organic or inorganic. There are also fears that more contamination will be in the particulate forms as hydrocarbon droplets. These pollutants, mostly common in third-world countries when contaminated with coronavirus, can increase the infection rate in an area. Several studies [16] laid the foundation for understanding the association of pollen contamination, respiratory and cardiovascular disease. For instance, there is a clear-cut understanding that airborne pollen concentrations significantly associate respiratorydisease rate and mortality in a particular environment. Thus, the changes in the pollution level, to a large extent, influence the level of pollutant contamination and transmission of contaminated pollen across environmental spaces. With unchecked air pollution levels and heavy presence of vapour and particulate pollutants, pollen contamination with coronavirus is expected to be high with a higher than normal infection rate. The variability from one city to the other will be dependent on economic activities in the area and the public lifestyles, including sanitation level. 


\subsubsection{Red Flags for Air Pollutants in the Human System}

Depending on pollutants' hydrophilicity and hydrophobicity, which is aided by tissue absorption capacity and fluid dissolution, contaminated pollen or particulates can reach the human airways in the lungs and can spread to the entire human systems, organs, and tissues aided by blood flow with rapid attacks due to their easy multiplicity. The probability of respiratory infections under such situations, including the dreaded covid-19, is high. Other negative underlying respiratory conditions relative from person to person, such as asthmatic conditions, chronic bronchitis, indoor pollution, lifestyle (e.g., smoking), further exacerbate the vulnerability and infection rate.

\subsection{Water Pollution}

The most infectious disease does not enjoy indemnity from water pollution, and the novel virus poses high infection rates with water pollution, which studies by Ahmed et al. [17] have indicated to abet the disease. Like atmospheric contamination, water contamination is a strong condition for the spread of any infection or contagious disease, including coronavirus [18]. Despite that, water pollution is low in Africa than in other continents due to low industrialisation [19]; unfortunately, most third-world countries like Nigeria are still facing the problem of potable water. According to Qu et al. [20], this condition (negative environmental factors) reinforces the negative valence of the virus, which has shown to survive well in polluted water. Consider that, despite Australia's developed status, there is proof of first confirmed detection of SAR-CoV-2 in untreated water in Australia [17], how much more in third-world countries like Nigeria without good or portable water [21]. Genthe et al. [21] maintained that contaminated water has high human health risks, especially in relation to contamination elements in the form of metalloids, which are found in drinking water, vegetables, and river catchments. With the presence of the novel virus in the waterways and daily water access, the people's chance of infection is high. Also, the process of accessing portable water in the third, which involves physical contacts, increases the risk of exposure and infection to covid-19. For instance, in Nigeria, rural dwellers still fetch their water from streams, while in cities, many families cue up to public taps. These activities themselves are exposed to the virus.

Also, Barcelo [8] established the dangers of water pollution and exposure to untreated water, which is believed to propagate the virus; for instance, examining sewage epidemiology, Barcelo [8] found that the virus, which is the vector of covid-19, can survive via faeces found in the sewage water for several hours. The novel virus can also be passed from the gastrointestinal tract during defecation into the sewage water with high potential for infection in areas where there is public usage of bathrooms and toilets. This typically defines the third world vulnerability more than other regions.

\subsubsection{Critical Health Vulnerabilities of Water Pollution}

The coronavirus can pollute the water both when it comes in contact with the water sources either as vapour droplets or in the form of dissolution into the water. The contamination of water has been known to be the major source of illness for ages [22]. The threat of coronavirus may be higher when the virus is in proximity with the leading causes of water pollution such as: domestic sewage, unprofessional handling of industrialisation materials, pesticides and fertilisers usage, contaminated plastics and polythene bags (which often find their way to the sources of water), poor urbanisation behaviour (flooding, poor drainages). These may contaminate water sources if they are already compromised by the coronavirus.

\subsubsection{Red Flags for Water Pollutants in the Human System}

Coronavirus is both physically contagious and infectious by droplets, which places water contamination as the greatest threat of spreading the virus. Waterborne diseases are usually difficult to manage because water is a universal solvent with which everybody comes in contact every minute of the day. Contaminated water increases disease spread man to man [23]. Rainfall in the time of this pandemic is also problematic as infected people and contaminated objects come in contact with people who readily move around under the rain. Water contamination increases the risk of diseases (e.g., respiratory disease, cancer, diarrheal disease, neurological disorder, and cardiovascular disease), which catalyse coronavirus into critical health situations.

\subsection{Public Sanitation and Personal Hygiene}

Another evaluation was also made on the dangers of poor public sanitation and poor personal hygiene as factors that could abet the upward surge of the infection rate in the third-world countries; the disease is a contact disease. Being propagated by air droplets being protected against the virus necessarily demands 
high public and personal hygiene levels, especially now the lockdown is being eased.

Announcing the rational use of personal protective equipment (PPE) against coronavirus disease (COVID19), WHO [24] emphasised that the use of PPE alone does not guarantee safety without spirited effort on public and personal hygiene, including social distance and reduce the use of body parts especially ones used in the face. This is supported by the study carried out by Abdulrahman et al. [25], which supported that various personal hygiene habits could reduce exposure to influenza-like illness, which is the family of the novel coronavirus. There is evidence in Gizaw et al.'s [26] study that water sanitation and personal hygiene could reduce levels of exposure and infection of contagious diseases in Ethiopia. In the annexe report of the WHO [27], it equally emphasised the non-pharmaceutical public health measures for mitigating the risk and impact of epidemic and pandemic and among the measures are public sanitation, personal hygiene, and physical protection of the self. This report validated the study by Sari et al. [28], which emphasised the use of personal protective equipment and maintenance of personal hygiene among scavengers as a way of protection against disease.

Given-that the third world peculiarities present challenges on the efficacious practice of personal hygiene such as availability of clean water for regular washing of hands, cooking, bathing, watching of clothing exposed outside, having good disposal for dirt, and urinary and toilets. Public sanitation is also endangered with poor waste management, poor sewage treatment, and disposal and lack of potable water for regular environmental cleanliness.

\section{DISCUSSION}

No doubt, third-world countries have peculiar environmental-health challenges that stem from underdevelopment and poor management of resources due to public service and institutional corruption [29]. These challenges seem to abet the infectious disease epidemiology, and coronavirus may not be an exception despite its high contagious nature. Personal hygiene in the third world seems to be driven by the level of public awareness and public sanitation. High exposures to environmental challenges such as air and water pollution in the third world remain uncontrolled due to poor regulations and poor government framework on offenders. Emission control laws are not yet enforced in the third world as much as they are in developed countries. Access to potable water remains one of the greatest health challenges in Africa and adversely affects the management and control of infectious diseases, especially waterborne diseases.

With coronavirus able to survive in water and being carried as air droplets by air pollution, the case fatality ratio in Africa will be high than it is supposed given Africa's initial and moderate exposure to the pandemic. The greater problem to these environmental challenges (air and water pollution, personal hygiene, and public sanitation) is in the government's inability to provide alternatives to essentials, e.g., water and personal protective equipment (PPE). With unregulated markets, housing, public facilities (hospitals, schools, sewage, etc.), the impacts of poor personal hygiene and poor public sanitation on the infection rate of the virus will be higher than normal in developing countries. On personal hygiene, poor and wrong use and handling of PPE will most likely increase CFR. Lack of government enforcement on environmental degradation at this time of the pandemic due to corruption will also have adverse effects on the epidemiology of the disease as sanitation officers compromise will prove costly to the disease infection rate.

\subsection{Implications}

Given Africa's moderate exposure to the pandemic, it isn't expected that the case fatality ratio's prediction will be exceeded. Sadly, this may be surpassed no thanks to environmental health challenges which have plagued third world countries for several decades. There is evidence that with poor health facilities and irresponsive government in the third world, the path of the epidemiology of any novel pandemic will be different. The differential lies in peculiarities of poor environmental health than the morphology of the disease.

\section{CONCLUSION}

The coronavirus pandemic, which started in Wuhan China, spread so fast that it engulfed the whole world. This study specifically evaluated the environmental dynamics of the pandemic amidst the growing fatality rate in many parts of the under-developed and developing countries that are generally referred to as Third World Countries. In these countries, managing air and water pollution remains very problematic. Individuals, groups, and government groups find it difficult to manage the environment, and when there is an epidemic, it will spread with the speed of light as the 
pollutants in the environment help to trap, house, sustain and spread infections, thereby causing mass fatalities.

Therefore, this study reviews these peculiarities in the light of their current concern in public health as per their contribution to the persistent surge in CFR in most developing nations. Ironically, the fact that the pandemic is transmitted with the speed of light calls to mind the fast-moving environmental implications of the virus. Given that the virus is transmitted via droplets, the review focused on how the state of public and environmental challenges such as air as well as water pollution and personal hygiene could be abetting the surge in coronavirus infections and morbidity. The review revealed, among other things, that challenges associated with poor sanitary conditions, lack of potable water, unventilated environments, air pollution, and poor inter-personal hygiene are devastating challenges in the fight against the pandemic.

Finally, there is a need for personal, domestic, group and government conceited efforts to manage all forms of pollutions in the global village to ensure the increased security of the environment for the current and future generations.

\section{REFERENCES}

[1] World Health Organization. Coronavirus disease 2019 (COVID-19): Situation report 2020; 72.

[2] Omer SB, Malani P, Del Rio C. The COVID-19 pandemic in the US: a clinical update. JAMA 2020; 323(18): 1767-1768. https://doi.org/10.1001/jama.2020.5788

[3] Worldometers.infor/coronavirus 2020.

[4] Sen-Crowe B, McKenney M, Elkbuli A. Social distancing during the COVID-19 pandemic: Staying home save lives. The American Journal Of Emergency Medicine 2020; 38(7): 1519-1520.

https://doi.org/10.1016/j.ajem.2020.03.063

[5] Anderson RM, Heesterbeek H, Klinkenberg D, Hollingsworth TD. How will country-based mitigation measures influence the course of the COVID-19 epidemic? The Lancet 2020; 395(10228): 931-4.

https://doi.org/10.1016/S0140-6736(20)30567-5

[6] Shigemura J, Ursano RJ, Morganstein JC, Kurosawa M, Benedek DM. Public responses to the novel 2019 coronavirus (2019-nCoV) in Japan: Mental health consequences and target populations. Psychiatry and Clinical Neurosciences 2020; 74(4): 281. https://doi.org/10.1111/pcn.12988

Ouyang X, Shao Q, Zhu X, He Q, Xiang C, Wei G. Environmental regulation, economic growth and air pollution: Panel threshold analysis for OECD countries. Science of the Total Environment 2019; 657: 234-241. https://doi.org/10.1016/j.scitotenv.2018.12.056

[8] Barcelo D. An environmental and health perspective for COVID-19 outbreak: Meteorology and air quality influence, sewage epidemiology indicator, hospital disinfection, drug therapies and recommendations. Journal of Environmental Chemical Engineering 2020; 8(4): 92-101. https://doi.org/10.1016/j.jece.2020.104006
Zhao Z, Li X, Liu F, Zhu G, Ma C, Wang L. Prediction of the COVID-19 spread in African countries and implications for prevention and controls: A case study in South Africa, Egypt, Algeria, Nigeria, Senegal and Kenya. Science of the Total Environment 2020; 729; 458-469. https://doi.org/10.1016/j.scitotenv.2020.138959

[10] Núñez-Delgado AN. What do we know about the SARS-1 CoV-2 coronavirus in the environment? Sci. Total Environ 2020; 727. https://doi.org/10.1016/j.scitotenv.2020.138647

[11] Fattorini D, Regoli F. Role of the chronic air pollution levels in the Covid-19 outbreak risk in Italy. Environmental Pollution 2020; 114732.

https://doi.org/10.1016/j.envpol.2020.114732

[12] Nishiga M, Wang DW, Han Y, Lewis DB, Wu JC. COVID-19 and cardiovascular disease: from basic mechanisms to clinical perspectives. Nature Reviews Cardiology 2020; 1-16. https://doi.org/10.1038/s41569-020-0413-9

[13] Zhou C, Li S, Wang S. Examining the impacts of urban form on air pollution in developing countries: A case study of China's megacities. International Journal Of Environmental Research And Public Health 2018; 15(8): 1565 https://doi.org/10.3390/ijerph15081565

[14] Li J, Sun S, Tang R. Major air pollutants and risk of COPD exacerbations: a systematic review and meta-analysis. Int' Journal Chronic Obstr Pulm Dis 2016; 11: 3079-3091. https://doi.org/10.2147/COPD.S122282

[15] Bloemsma LD, Hoek G. Smit LA. Panel studies of air pollution in patients with COPD: systematic review and metaanalysis. Environ Res 2016; 151: 458-468. https://doi.org/10.1016/j.envres.2016.08.018

[16] Brunekreef B, Hoek G, Fischer P, Spieksma F. Relation between airborne pollen concentrations and daily cardiovascular and respiratory-disease mortality. The Lancet 2001; 355(9214): 1517-1518.

https://doi.org/10.1016/S0140-6736(00)02168-1

[17] Ahmed W, Angel N, Edson J, Bibby K, Bivins A, O'Brien JW, Tscharke B. First confirmed detection of SARS-CoV-2 in untreated wastewater in Australia: A proof of concept for the wastewater surveillance of COVID-19 in the community. Science of The Total Environment 2020; 138-146. https://doi.org/10.1016/j.scitotenv.2020.138764

[18] Randazzo W, Truchado $P$, Cuevas-Ferrando E, Simón $P$ Allende A, Sánchez G. SARS-CoV-2 RNA in wastewater anticipated COVID-19 occurrence in a low prevalence area. Water Research 2020; 115942. https://doi.org/10.1016/j.watres.2020.115942

[19] Fayiga AO, Ipinmoroti MO, Chirenje T. Environmental pollution in Africa. Environment, Development and Sustainability 2018; 20(1): 41-73. https://doi.org/10.1007/s10668-016-9894-4

[20] Qu G, Li X, Hu L, Jiang G. An imperative need for research on the role of environmental factors in transmission of novel coronavirus (Covid-19) 2020.

\section{https://doi.org/10.1021/acs.est.0c01102}

[21] Genthe B, Kapwata T, Le Roux W, Chamier J, Wright CY. The reach of human health risks associated with metals/metalloids in water and vegetables along a contaminated river catchment: South Africa and Mozambique. Chemosphere 2018; 199: 1-9. https://doi.org/10.1016/j.chemosphere.2018.01.160

[22] Briggs D. Environmental pollution and the global burden of disease. British Medical Bulletin 2003; 68: 1-24. https://doi.org/10.1093/bmb/ldg019

[23] Halder JN, Islam MN. Water pollution and its impact on the human health. Journal of Environment and Human 2015; 2(1): 36-46.

https://doi.org/10.15764/EH.2015.01005 
[24] World Health Organization. Rational use of personal protective equipment (PPE) for coronavirus disease (COVID19): interim guidance, 19 March 2020 (No. WHO/2019nCoV/IPC PPE_use/2020.2). World Health Organization.

[25] Abdulrahman AKB, Abdulrahman KAB, Almadi MK, Alharbi AM, Mahmoud MA, Almasri MS, Al Fraih MA. Do various personal hygiene habits protect us against influenza-like illness? BMC Public Health 2019; 19(1): 13-24. https://doi.org/10.1186/s12889-019-7726-9

[26] Gizaw Z, Addisu A, Dagne H. Effects of water, sanitation and hygiene (WASH) education on childhood intestinal parasitic infections in rural Dembiya, northwest Ethiopia: an uncontrolled before-and-after intervention study. Environmental Health And Preventive Medicine 2019; 24(1): 1-8. https://doi.org/10.1186/s12199-019-0774-z

[27] World Health Organization. Non-pharmaceutical public health measures for mitigating the risk and impact of epidemic and pandemic influenza: annex: report of systematic literature reviews (No. WHO/WHE/IHM/GIP/2019.1). World Health Organization 2019

[28] Sari NK, Rahardjo SS, Widyaningsih V. Factors associated with personal hygiene, use of personal protective equipment, and the risk of contact dermatitis among scavengers: A path analysis evidence from Surakarta, Central Java. Journal of Health Promotion and Behavior 2019; 4(3): 198-211. https://doi.org/10.26911/thejhpb.2019.04.03.05

[29] Ezeh LN, Etodike CE. Corruption in Nigeria organizations: Theories \& implications. In Osinowo $\mathrm{H}$, Zamani $\mathrm{A}$, ObiNwosu H, Afolabi OL, Nwafor CE, Eds. Peace, Inclusive Societies and Psychology Proceedings of Annual Scientific Conference of Nigeria Psychological Association (NPA), held at Nnamdi Azikiwe University Awka, Nigeria, 11th - 14th Oct. 2016; pp. 87-100.

https://doi.org/10.6000/2292-2598.2021.09.01.5

(C) 2021 Etodike et al.; Licensee Lifescience Global.

This is an open access article licensed under the terms of the Creative Commons Attribution Non-Commercial License (http://creativecommons.org/licenses/by-nc/3.0/) which permits unrestricted, non-commercial use, distribution and reproduction in any medium, provided the work is properly cited. 